\title{
Domestic Violence towards Women Characters as Seen in Toni Morrison's The Bluest Eye
}

\author{
Ichwati Yuliana, Fabiola Dharmawanti Kurnia, Ali Mustofa
}

Postgraduate Program of English Education and Literature, Surabaya State University, Indonesia

\begin{abstract}
This paper aims to unfold the forms of domestic violence towards women main character in Toni Morrison's The Bluest Eye. It employs subaltern theory by Gayatri Spivak and domestic violence theory by Ganely, to investigate and answer the problem. The analysis discovers that Pecola Breadlove, the woman main character in this novel, suffers from domestic violence in the form of sexual, physical and psychological. She is firstly abused sexually by his father when she is in a very young age. This incestuous behavior remain deeply traumatic in her psychology. Moreover, Pecola who craves for blue eyes believes that by those eyes, her life will be changed since she will be well accepted by her community. Her existence in her community is hated because they consider her as an ugly girl. Moreover, she receives violence not only in sexual, verbal, but also in physical. Finally, this paper concludes that domestic violence is as the manifestation of dominating behavior from someone over other. The superiority leads someone to discriminate and abuse to others. In order to be well accepted in both black and white community and to overcome her sorrow life, thus she prays and craves for blue eyes.
\end{abstract}

Keywords_-Domestic violence, violence, subaltern, black people, Toni Morrison.

\section{INTRODUCTION}

The number of domestic violence victims is higher towards women compared to men. According to WHO, intimate partner violence (IPV) is described as the most frequent domestic violence. In worldwide, almost one third $(30 \%)$ of women who have been in a relationship report that they have experienced some form of physical and/or sexual violence by their intimate partner in their whole life (Garcia-Moreno, 2012). It reveals that women are more vulnerable because they are usually categorized as subordinate to men. He further stated that every man in a dominant position and a woman will be a subordinate (Walby, 1990).

Moreover, in the patriarchy culture system in society men are seen as superior. Furthermore, patriarchal culture becomes deeply rooted and dominant in social life. The patriarchy system in social structures encompasses men's domination, oppression, and women exploitation (Walby, 1990). Men's domination is very strong in society and especially in a rural society where women are always dominated by men and considered as weak. The given label for women as weak shows that women are perceived as a second class person. This perception also drives men to do violence towards women. Thus, in a patriarchal society where men feel more superior to women, violence is more likely to happen especially in the domestic area.

Domestic violence occurs as a pattern of abusive and coercive behaviors. It concerns physical, sexual, and mental assault, as well as economic coercion that adults use against their intimate partners (Schecter \& Ganley, 1995:16). This further suggests that domestic violence could occur in some aspects, such as physical, sexual, psychology, and economic aspects. Domestic violence has been around throughout recorded history. In some societies, women were traditionally considered as the man's asset; he has the power to control and punish them and the children physically for instance beatings (Summers, 2001).

The Bluest Eye (1970), written by Toni Morrison, presents racism and oppression among the blacks and the whites in the United States. The black character is represented by Pecola, the main character, who is treated badly by the whites and the blacks who consider themselves as whites. Pecola feels inferior and envies to have blue eyes so that she is not under oppression by the whites who are more superior to the blacks. As a consequence, the black main character experiences physical and mental oppression as the result of the violent assault whether physically or language. 


\section{LITERATURE REVIEW}

This subchapter encompasses two parts; the first is about the concept of subaltern by Gayatri Chakravorty Spivak and domestic violence theory. Then, the review of some previous studies will be in the second section.

Subaltern term was adapted from Antonio Gramsci to refer subordinate workers. In postcolonial studies, the term is used to relate to individuals or groups who are dominated or oppressed by superior or powerful others within the colonized society (Moretona, 2008: 8)

Another postcolonial intellectual, Gayatri Chakravorty Spivak,(1988) uses the term 'subaltern' in her essay 'Can the Subaltern Speak?'. She mentions that the domination of males in patriarchal society places women in a secondary position and gives an inferior role. She answers it by connecting to the context of colonial production that subaltern has no history, it cannot speak, and female as the subaltern is even in shadow more deeply (Spivak, 1988: 83). She further explains that in postcolonial literature, women are underestimated and underrated to men. Spivak employs a subaltern to show the women in a lower and marginalized status in society.

Women among men seem to have no voice to sound their rights. It does not mean that they cannot speak in literal meaning. However, they cannot speak out their position or condition because they are subordinated positions in society. The women's voice is not recognized and registered in society due to the lack of accessibility to a public area. Also, Spivak states that subaltern means the oppressed subjects are those who are inferior rank (1988:283). In a similar context to Gramsci in using the term subaltern, she believes that a weak economic position and dispossession portray the subalterns who are not able to articulate themselves.

Spivak categorizes the subaltern by considering the subjects based on gender and Indian Women in specifically since they are as colonialist historiography object and as a subject of rebellion over the dominance of men of ideological structure. Spivak concludes that the position of Indian Women through some analysis are as subaltern who cannot speak. And the only way to able them to speak is by dominating language so that they can be heard. Unluckily, it is possible to gain that position without the oppression (Ashcroft, Bill Griffiths, Gareth and Tiffin, 2000:201). Furthermore, Gayatri tells that rules, laws, and culture in society control women's oppression in any aspect (Jouzaee, 2014:1525). The men domination in society leads them to be a leader and lead the women to obey them. This domination makes women have a lower position than men. As a result, women have more anxiety, helpless identity, and rebellious attitude in a patriarchal system.

According to Ganley (1995), domestic violence is "a pattern of attack and coercion in the form of physical, sexual, and psychological assaults, including economic duress. Adults or adolescents commonly conduct this type of violence against their close counterparts". Edward (1996) said that "domestic violence has a character of physical and mental coercion, from a slap leading to a shove to a punch or kick, and the more extreme epitome of violence, in suffocation, strangulation, attempted murder and murder."

Domestic violence generally happens in relationships where the perpetrator and victim have close connections shared between them. This kind of violence may occur to any intimate relationship that either adolescent or adult experience.

Domestic Violence forms:

\section{1) Physical Abuse}

Physical abuse has wide various types of behavior, including "grabbing, shaking, shoving, pushing, spitting, scratching, punching, choking, throwing, twisting, slapping (open or closed hand), burning, and using weapons (household objects, knives, guns) against the victim. The other attacks cause physical injuries and some others do not. The acts that seem less harmful or direct may cause the most critical injury. The perpetrator commonly pushes the victim against a wall or a floor, down a flight of stairs, or out of moving vehicles. The consequences of those acts may continue to affect one's psyche until they experience form varying degrees of trauma (e.g., bruising, broken bones, and spinal cord injuries).

\section{2) Sexual Abuse}

Sexual abuse happens when the abuser forces sexual activity without the woman's own will. According to Wiehe (1998), it is also understood as marital rape. The male commonly has full right and privilege to conduct intercourse whenever he wants and in any form he desires, regardless of his female' feelings. Stereotyped sex roles in society promote an increased possibility of sexual abuse. Some women feel they cannot decide on their own because they do not realize their rights. They will do their partners favor according to their demands, and it should be taken for granted. Sexual abuse includes: sexual assault, sexual harassment, and sexual exploitation.

3) Psychological Abuse 
Emotional abuse is one of the forms of violence on the relationship indicated by a pattern of behaviors that causes an injury to an innocent counterpart (Gordon, 2010:23). According to his view, emotional abuse can be divided into two. If the victim is a child, emotional abuse means unable to prevent others from harming that may conduce mental, emotional, or mental and emotional injury that deface a child's growth, development, or psychological functioning.

Meanwhile, if the victim is an adult, emotional abuse can be defined as an act that conduces mental pain, sorrows, suffering, or extreme tension through verbal or nonverbal acts such as ignoring, terrorizing, stalking, underestimating, mocking, insulting, harassing, threatening, intimidating or corrupting. These acts result in damage to mental and emotional health. The victim of these acts will later experience visible and material disability, and psychological dysfunction.

Besides the two theories mentioned, the writer also reviews some previous studies conducted by literary researchers or theories related to subaltern, oppression or violence. The first study was conducted by Irfan Mehmood (2019) entitled "An Exploration of Characteristics of Marxist Feminist Theory in Toni Morrison's Novels, The Bluest Eye and Beloved". Here, this study attempts to explore the notion of women exploitation by discrimination of gender and oppression through economics. He applied Marxist Feminist theory to investigated Toni Morrison's novels, The Bluest Eye and Beloved. According to him, the usage of this theory to examine and explain the ways how the women are oppressed through the capitalism and patriarchy system. The second study entitled "The Bluest Eye: A Tragedy of Oppression and Internalized Racism "was conducted by Neelam Bhardwaj (2016).This study revealed the "colored" people were considered as inferiors since they were degraded as a lower class due to their race or skin color. She further found that black women especially were victimized not only by race and sex but they were treated badly also by class exploitation.

\section{METHOD}

This study uses a context-oriented approach to literary criticism that employs the subaltern concept outlined by Gayatri Spivak and other relevant theories related to subaltern which is one of the forms of dominance over women that leads to violence. Spivak's theory is used to examine the violence as manifested of oppression by the dominants towards woman main characters in Toni Morrison's The Bluest Eye. The main data contains words, phrases, sentences, statements, dialogues as well as monologues collected from Toni Morrison's The Bluest Eye. The data are examined and elaborated to identify domestic violence forms faced by Pecola Breedlove.

\section{FINDINGS}

This subchapter presents the findings of forms of domestic violence suffered by Pecola Bredlove. Those domestic violence forms are elaborated in the following paragraph.

\section{Psychological Violence}

This novel presents racism and oppression among the blacks and the whites in the United States. The black character is represented by Pecola, the main character, who is treated badly by the whites and the blacks who consider themselves as whites. Pecola feels inferior and envies to have blue eyes so that she is not under oppression by the whites who are more superior to the blacks. As a consequence, the black main character experiences physical and mental oppression as the result of the violent assault whether physically or language.

The poor little black Pecola who is always mocked by everyone for her blackness and ugliness craves for blue eyes to be loved and accepted by her community and including her family too. It can be seen as the following quotation.

"if those eyes of hers were different, that is to say, beautiful, she herself would be different. Her teeth were good, and at least her nose was not big and flat like some of those who were thought so cute. If she looked different, beautiful, maybe Cholly would be different, and Mrs. Breedlove too.” (Morrison, 1970: 46)

This excerpt shows that Pecola physical appearance is disreputable. It is only people around her who scorn for her ugliness but also closest people, her father and mother, do not accept her. The criteria of beauty that based on white skin, blonde hair or blue eyes make her becomes rejected. Pecola embeds the concept of beauty echoed by the dominant culture as she is as the victim of white controlling image of beauty and perfection.

Being scorned in her daily life makes Pecola becomes silent, loveless, lost self-esteem and unconfident girl. She grows in traumatic life. When she is at school, she cannot resist being ridiculed by her friends and teacher about the color of her skin.

"Her teachers had always treated her this way.

They tried never to glance at her, and called on her only when everyone was required to 
respond. She also knew that when one of the girls at school wanted to be particularly insulting to a boy, or wanted to get an immediate response from him, she could say." (Morrison, 1970:46-47)

She is harassed by her schoolmate and her teacher for being black and ugly. She receives verbal assault from her peers who humiliate her for the reason that she is having unattractive physical appearance.

"Bobby loves Pecola Breedlove! Bobby loves Pecola Breedlove!" and never fail to get peals of laughter from those in earshot, and mock anger from the accused." (Morrison, 1970: 46)

Moreover, she is not only harassed by the white kids but also by her own race too. Every day is miserable for Pecola. They bully her verbally by calling her 'black e mo' (Morrison, 1970: 62). Facing verbal bullying shatters her psychology. She feels has no value in her life.

\section{Physical Violence}

The physical violence is described as any various behaviors that cause physical injuries or evidence in someone body. The consequences may affect to someone psyche and continue to various degree of trauma. In Pecola, she gets physical violence from her mother.

"Mrs. Breedlove yanked her up by the arm, slapped her again, and in a voice thin with anger, abused Pecola directly..." (Morrison, 1970: 85)

Violence becomes prominent in Pecola's life. Almost every day, she accepts bad behavior and attitudes. Her parents become the perpetrator of the physical assault. From the excerpt above, it tells that the harassment become her daily treatment as a consequence of her ugliness. Pecola has a poor relationship with her mother. Her mother abuses her because she is in a position of power above her. The little Pecola is weaker physically than her mother so it is easy for Pauline to overpower her. Oppressing a child is easy for parent because she or he is unable to protect or fight back his or her oppressor. Pecola knows that she has no power to harm back her parents so she tries to find out her own ways to escape from this oppression by changing herself or accepting the oppression. Pecola never complain of what they have done to her. She would rather play with her two friends, Claudia and Frieda, than express what she feels to them.

\section{Sexual Violence}

Sexual abuse occurs when the perpetrator uses a force for sexual purposes or involve a child in sexual act. Pecola is firstly abused sexually at the hand of her father Cholly. He rapes her daughter when she is at the kitchen about washing the dishes, then he approaches and flirt her.

"A desire to cover her foot with his hand and gently nib-ble away the itch from the calf with his teeth. He did it then, and started Pauline into laughter. He did it now." (Morrison, 1970: 164)

She is helpless knowing her father does incestuous behavior to her. She is too powerless to step away from Cholly. She has no power or control over her father since he is more powerful than her. Eventually, she has to face sexual violence by the hand of her own father. It is a shame for her. The little Pecola is oppressed to participate in sexual act in order to satisfy her father desire. This incestuous leaves Pecola in a psychological trauma. Besides, it also results Pecola impregnate. This rape result lowers Pecola self-esteem

\section{DISUSSION}

In the Bluest Eye, Pecola Breedlove has to deal with both the white people and the people from her race. The white supremacy brings oppression and discrimination for the black people who are considered as inferior or second class. The beauty standard that is valued by the white affect the black people in viewing and framing beauty concept among their community too. Pecola is not only as the victim of the white oppression but she is rejected by her race too since she is black and ugly. Her schoolmates, teacher, family and community victimize her as if she deserves that. They always scorn and humiliate her whenever she is. Pecola has bad relationship with her family. Her mother has no concern and attention to her. She even rejects her as Pecola is born due to of her ugliness. While, her father rapes and impregnate her. Cholly is a drunkard, abandoned by his father and assaulted sexually by two white men. When he assaults his daughter sexually seem he has no guilty to her daughter. As he is abused at childhood, it is difficult for him to make good relationship.

Pecola does not find any love and attention from her family and in her black community too. Born into violent and loveless family make her inferior and alienated. Having miserable life, Pecola obsesses to have white skin and beauty thus everyday she goes to church to pray for blue eyes. Pecola believes that having those criteria will make people happy and kind to her. Pecola has got trauma in her life since she is harassed physical, emotional, and sexual. 


\section{CONCLUSION}

The points to conclude this study related to Spivak's idea of subaltern is that the hegemony and domination of white people toward black make them as the object of oppression and being marginalized. The white beauty standard impacts to the society mainly the black. When the white skin, blue eyes and pretty face are considered as beauty standard by people, those give impact psychologically and physically for those who unluckily do not have those standard. Being superior tend people to dominate and control others because they feel better than other people. The black people is not accepted in their society since they are less attractive physical. It is an oppression for the women especially since it become unbearable burden. For black people, white beauty standard hegemony is a form of oppression.

Moreover, in this novel, Pecola, the main character, is represented how the black is rejected and neglected from the community, both from the white and the black. She has to face the reality and accept it because she is born black and ugly. In order to escape from her sorrow, she prays for having blue eyes. According to her, having blue eyes she will be accepted and her life will change. She wants her family, friends and community accept her the way she is yet it does not happened to her. It is unbearable for her to always receive violence for the reason of her ugliness and unattractiveness.

\section{REFERENCES}

[1] Ashcroft, Bill Griffiths, Gareth, and Tiffin, H. (2000). Key Concept of Post-Colonial Studies

[2] Bhardwaj, Neelam. (2016). The Bluest Eye: A Tragedy of Oppression and Internalized Racism. International Journal on Studies in English Language and Literature. Vol.4.

[3] Edwards, Susan S.M. (1996). Sex and Gender in the Legal Process. London. Blackstone Press.

[4] Ganley, A. L., \& Schechter, S. (1996). Domestic violence: A national curriculum for children's protective services. San Francisco, CA: Family Violence Prevention Fund.

[5] Jouzaee, S. A. \& J. L. B. (2014b). Double Colonization of Indian Women in Amitav Ghosh's Sea of Poppies. Journal of Novel Applied Sciences, 1524-1530.

[6] Mehmood, Irfan. (2019). An Exploration of Characteristics of Marxist feminist Theory in Toni Morrison's Novel, The Bluest Eye and Beloved. Journal of Multidisciplinary Approaches n Science, Vol..

[7] Moretona E. (2008). Restoring the history of the Subaltern: A corpus informed study of the history of Mary Prince, A West Indian slave. A Thesis in the Department of Humanities, School of English, University of Birmingham.

[8] Morrison, Toni. (1970).The Bluest Eye. London: Vintage Books.
[9] Spivak, G. C. (1988). Can the Subaltern Speak? Marxism and the Interpretation of Culture. Macmillan: Basingstoke, 1988, Pp. 271-313. Retrieved fromhttp://www.mcgill.ca/files/crclawdiscourse/Can_the_ss baltern_speak.pdf

[10] Summers, Randal W. (2001). Domestic Violence: A Global View. Greenwood

[11] Walby, Sylvia. (1990). Theorizing patriarchy. Oxford: Blackwell.

[12] Wiehe,V.R. (1998). Understanding family violence. Treating and preventing partner, child, sibling and elder abuse. Thousand Oaks, London, New Delhi: Sage Publications. 